\title{
Field data set of different cropping systems for agro- ecosystem modelling from Müncheberg, Germany
}

\author{
Wilfried Mirschel ${ }^{1}$, Dietmar Barkusky² , Kurt Christian Kersebaum ${ }^{1}$, Liane Laacke ${ }^{3}$, Karin Luzi ${ }^{1}$, Gunhild \\ Rosner $^{4}$, Karl-Otto Wenkel ${ }^{1}$ \\ ${ }^{1}$ Leibniz Centre for Agricultural Landscape Research (ZALF), Institute of Landscape Systems \\ Analysis, Eberswalder Str. 84, 15374 Müncheberg, Germany. \\ ${ }^{2}$ Leibniz Centre for Agricultural Landscape Research (ZALF), Experimental Station, Eberswalder Str. \\ 84, 15374 Müncheberg, Germany. \\ ${ }^{3}$ Leibniz Centre for Agricultural Landscape Research (ZALF), Department of Landscape Information \\ Systems, Eberswalder Str. 84, 15374 Müncheberg, Germany. \\ ${ }^{4}$ Leibniz Centre for Agricultural Landscape Research (ZALF), Institute of Land Use Systems, \\ Eberswalder Str. 84, 15374 Müncheberg, Germany. \\ * e-mail: wmirschel@zalf.de
}

\begin{abstract}
A coherent field data set (1993-1998) for three different cropping systems (intensive, organic, extensive) under rain-fed conditions on the basis of the identical crop rotation (sugar beet winter wheat - winter barley - winter rye - catch crop) located at the Experimental Station with sandy soils (Eutric Cambisol) of the Leibniz Centre for Agricultural Landscape Research (ZALF) Müncheberg, Germany, is described in detail. Soil and crop processes as well as meteorological parameters were intensively monitored and all agro-management actions were meticulously recorded. The data set contains data for crop (ontogenesis, plant, tiller and ear numbers, above-ground and root biomasses, yield, carbon and nitrogen content), soil (water and nitrogen contents), weather (all essential meteorological parameters) and management (soil tillage, sowing, fertilization, and harvest). Additionally the data set contains the meta-information for the observations. The data set is available via the Open Research Data Portal at ZALF Müncheberg and is published under doi:10.4228/ZALF.1992.167. The data set was used within the international workshop "Modelling Water and Nutrient Dynamics in Soil-Water System" with the participation of 18 different models from nine countries.
\end{abstract}

Keywords: field experiment, cropping systems, crop-soil-weather-management data set, agroecosystem modelling, Müncheberg (Germany)

1 INTRODUCTION: Processes of land use and climate changes are going on continuously within agricultural landscapes at present. The shifts between forests, grassland and arable land are not so significant in Europe. The use of arable land by different cultivars, different crop rotations and different intensities is changing more quickly. Here especially the policy and the market are two of the drivers for changes in the use of arable land (Efroymson et al., 2016) and what will be happen under climate change in this field in future is not easy to predict. For the assessment of the impacts of these changes in agro-landscapes and for future scenario simulations it is necessary to use process-based agroecosystem models. This is the reason for the presence of a wide scientific community dealing with agro-ecosystem modelling such as STICS (Brisson et al., 2003), APSIM (Keating et al., 2003), DAISY (Hansen et al., 2012), HERMES (Kersebaum et al., 2014) or CROPSYST (Stöckle et al., 2003). All modellers need a wide experimental data base for model parameterization and model validation containing weather/climate, crop, soil and management data. For model development and model comparisons high quality and coherent data are necessary, conforming to a defined scientific standard (Kersebaum et al., 2015). On the basis of such data sets model comparisons and multi-scenario- I multi-model simulations were realized in the past already (Diekkrüger et al. 1995; Kersebaum et al. 2007; Kollas et al. 2015; Martre et al. 2015).

Since the beginning of the 1990s decade at the Experimental Station of the Leibniz Centre for Agricultural Landscape Research (ZALF) Müncheberg, Germany, there is a long tradition in field experiments with intensive and coherent measurements concerning all necessary soil, crop, weather, and management data. Consequently, in ZALF there also is a long tradition in process-based agroecosystem modelling: HERMES (Kersebaum, 2011), AGROSIM (Mirschel and Wenkel, 2007), and MONICA (Nendel et al., 2011).

From 1992 up to 1998 at the Müncheberg Experimental Station a field experiment under rain-fed and irrigated conditions was established first to investigate the influence of different cropping systems on crop and soil values/parameters and second to produce coherent data sets for agro-ecosystem 
modelling, model parametrization, model validation and model comparison. The cropping systems represent different management intensities: (1) intensive management, (2) organic management, and (3) extensive management. Nearby the experimental plots a continuously recording automatic meteorological station was established. The crop and soil variables were measured at weekly to monthly intervals. During the first three years of the experiment, the time intervals for measurements were shorter compared to the next years up to 1998.

The whole experimental data set has already been used previously for parameterization and validation of AGROSIM, an agro-ecosystem model family for winter wheat, winter rye, winter barley, sugar beet and catch crops developed at ZALF Müncheberg (Mirschel and Wenkel, 2007; Mirschel et al., 2001; Wenkel and Mirschel, 1995). The rain-fed component of the whole data set was used as one part of the data basis for the international workshop "Modelling Water and Nutrient Dynamics in Soil-Water Systems" held in ZALF Müncheberg in June 2004 with the participation of 18 different models from nine countries (Kersebaum et al., 2007). In the years after this international workshop, the ZALF Müncheberg digitally processed this comprehensive data set for rain-fed conditions as basis for the agro-ecosystem modelling community worldwide. Now this data set is available via the Open Research Data Portal of the Leibniz Centre for Agricultural Landscape Research (doi: 10.4228/ZALF.1992.167) (Mirschel et al., 2015).

\section{FIELD EXPERIMENT}

2.1 EXPERIMENTAL SITE: The experiment was located at the Experimental Station of ZALF in Müncheberg, Germany. Müncheberg is situated in the Northeastern German lowlands $\left(52^{\circ} 52^{\prime} \mathrm{N}\right.$ and $14^{\circ} 07^{\prime} \mathrm{E}$; altitude of $62 \mathrm{~m}$ a.sl), around $40 \mathrm{~km}$ east of Berlin and $40 \mathrm{~km}$ west of the Oder river. The experimental field has no slope. The soil at the field plots is a diluvial loamy sandy soil, a Eutric Cambisol according to the FAO classification. The groundwater table is deeper than $12 \mathrm{~m}$. The Experimental Station is located in the transition area between a maritime climate and a continental climate with cold winter periods (often without snow) and with drought periods mainly in May-June. For the time period 1990-2000 the mean annual precipitation sum is $527 \mathrm{~mm}$ and the mean annual temperature is $8.9^{\circ} \mathrm{C}$. The mean winter and summer temperatures in this decade are $0.6^{\circ} \mathrm{C}$ and $17.5^{\circ} \mathrm{C}$, respectively, and the mean winter and summer precipitation sums are $112 \mathrm{~mm}$ and $172 \mathrm{~mm}$, respectively. More detailed information about location and test site can be obtained from Mirschel et al. (2007).

2.2 EXPERIMENTAL DESIGN: The plots taken into account here represent only rain-fed plots of the complex field experiment, which has a split-block design with different management intensities and two water supply levels (rain-fed and irrigated). The management intensity factor is subdivided into an intensive cropping system (plot 1), an organic cropping system (plot 2), and an extensive cropping system (plot 3). In all cropping systems the crop rotation was sugar beet (Beta vulgaris subst. vulgaris), winter wheat (Triticum aestivum L.), winter barley (Hordeum vulgare L.), and winter rye (Secale cereale L.) with winter catch crops before sugar beet (oil radish at plot 1, yellow mustard at plot 2, and phacelia at plot 3).

The complex field experiment consists of four field trials ( $27 \mathrm{~m} \times 294.5 \mathrm{~m}$ each), each of which is subdivided evenly into three cropping system blocks with two sub-plots (21 m x $45 \mathrm{~m}$ each). In all cropping system blocks one sub-plot is the plot under rain-fed conditions. All plots are divided by border strips. Each plot has four $3 \mathrm{~m}$ strips where all measurements, including hand harvests, were executed, and two $3 \mathrm{~m}$ strips where the crop was harvested using a combine harvester. In the latter strips, the crop was able to grow undisturbed throughout the vegetation period. The automatic micrometeorological station is located nearby the experimental area. Figure 1 shows the location of the three plots within the field experiment.

2.3 AGRO MANAGEMENT: The three plots were treated with different intensities of management practices. The intensive cropping system at plot 1 with a traditional intensive tillage is realized on a high level using mineral fertilizer only and chemicals for pest management. Green manure from catch crops, straw and leaves as residuals from cereals and sugar beet are the only organic fertilizer. Within the organic cropping system at plot 2 with reduced ploughing regime only farmyard and liquid manure as organic fertilizers and biological as well as tillage methods against pest and weeds are used. The extensive cropping system at plot 3 with a moderate ploughing regime uses both mineral and organic fertilizers and chemicals for pest management. The intensity level here is about $50 \%$ of the intensive cropping system level. In all three cropping systems the sowing dates are the same, and all received the residues from catch crops and the leaves from sugar beet. Straw from cereals was ploughed in at plot 1 (intensive cropping system) and was exported from plots 2 and 3 (organic cropping system and 
extensive cropping system, respectively). The catch crops, the selected cultivars and the seed densities differ between all three cropping systems. So the seed density in the intensive cropping system is higher compared to the organic cropping system because of a better nitrogen supply and a higher pest management level.

The agro-management practices relevant for agro-ecosystem modelling documented here are:

- row distance $(\mathrm{cm})$

- sowing date (dd.mm.yyyy)

- germinable seed grains $\left(\mathrm{m}^{-2}\right)$

- emergence date (dd.mm.yyyy)

- harvest date (dd.mm.yyyy)

- residue management (green manure; straw ploughed in or exported; leaves from sugar beet ploughed in)

- fertilizer type

- amount of fertilizer (N, P,K, Mg; kg ha-1)

- date of fertilizer application (dd.mm.yyyy)

- soil tillage type

- tillage depth $(\mathrm{cm})$

- tillage date (dd.mm.yyyy).

Because of the bad weather conditions in 1993 the first sowing of sugar beet was not emerged and was ploughed up. For an emergence guarantee of the second sowing of sugar beet four weeks later at all three rain-fed plots three irrigation applications for emergence were realized (13.05.1993, 18.05.1993, 21.05.1993) with $6 \mathrm{~mm}$ each. Additional management information especially also on pest management practices is given in Wenkel and Mirschel (1995).

Figure 1. Location of plots within the field experiment at the Experimental Station of ZALF Müncheberg, Germany, (MMS - micro-meteorological station FMA 86 [type Weihenstephan, produced by Lambrecht GmbH Göttingen, Germany], photo: Rauneker, ZALF).

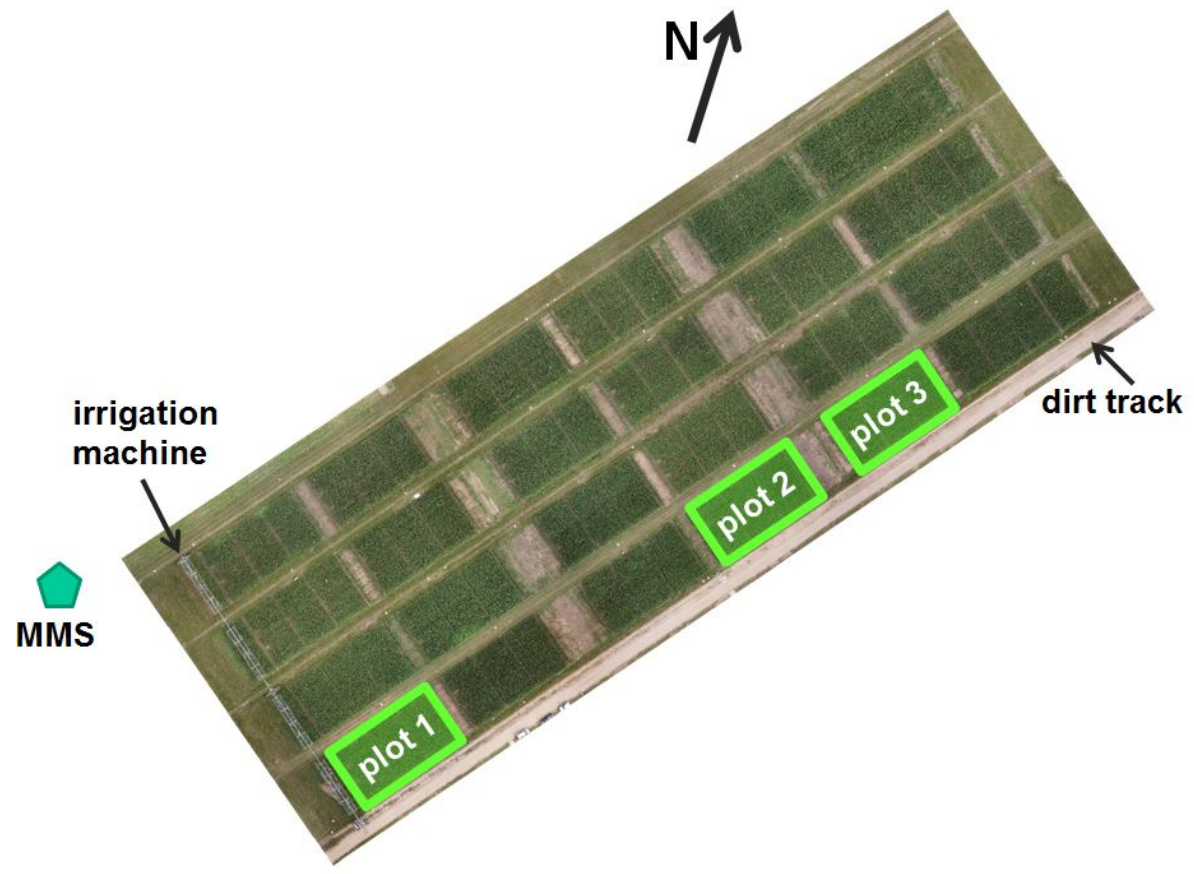

\section{MEASUREMENTS}

3.1 WEATHER DATA: Using an automatic micro-meteorological station (FMA 86 -type Weihenstephan, produced by Lambrecht GmbH Göttingen, Germany) nearby the experimental field plots the weather data were collected every ten minutes. The collected 10-minute-data were automatically aggregated to daily data. For measuring the precipitation a headed and wind-shielded gauge (type HP 3) with a sampling area of $200 \mathrm{~cm}^{2}$ coupled with a see-saw technique according to Joss-Tognini with a read contact (resolution: $0.1 \mathrm{~mm}$ ) was used. 
The measured weather data are:

- precipitation (at $1 \mathrm{~m}$ height, $\mathrm{mm}$ )

- mean, minimum and maximum temperatures (at $2 \mathrm{~m}$ height, ${ }^{\circ} \mathrm{C}$ )

- temperature at 14:00 (at $2 \mathrm{~m}$ height, ${ }^{\circ} \mathrm{C}$ )

- mean relative air humidity (at $2 \mathrm{~m}$ height, \%)

- relative air humidity at 14:00 (at $2 \mathrm{~m}$ height, \%)

- global radiation (at $2 \mathrm{~m}$ height, $\mathrm{J} \mathrm{cm}^{-2}$ )

- wind speed (at $2.5 \mathrm{~m}$ height, $\mathrm{ms}^{-1}$ )

- soil temperature (in $0.05 \mathrm{~m}$ depth, ${ }^{\circ} \mathrm{C}$ )

- soil temperature (in $0.2 \mathrm{~m}$ depth, ${ }^{\circ} \mathrm{C}$ )

- soil temperature (in $0.5 \mathrm{~m}$ depth, ${ }^{\circ} \mathrm{C}$ ).

Detailed information about sensors, their measuring ranges and accuracies are given in Wenkel and Mirschel (1995) and Mirschel et al. (2007). In the case if single sensors were out of order or the whole station didn't work no values were entered in the data set.

3.2 SOIL DATA: The randomised soil probes were sampled using manual methods. They were taken from three different soil layers $(0-30 \mathrm{~cm}, 30-60 \mathrm{~cm}$ and $60-90 \mathrm{~cm})$ in replicates using an auger as the basis for mixed probe for each field plot. These mixed probes were analysed in the ZALF-own laboratory. For sampling soil temperature an automatic method was used (see section 3.1).

3.2.1 SOIL WATER, SOIL NITROGEN, SOIL TEMPERATURE: For all soil probes the water content was determined gravimetrically by difference weighing before and after oven drying at a temperature of $105^{\circ} \mathrm{C}$. Soil sampling for determining soil mineral nitrogen and soil water content was carried out in accordance with the "N $\min$ Method" (Wehrmann and Scharpf, 1979). Mixed samples were formed from 12 to 14 auger samples. The samples were taken using a "Pürkhauer" half-cylindrical soil auger that was rammed into the soil down to a depth of $90 \mathrm{~cm}$. The mixed samples were transported in a cold box and analyzed the same day. Soil was extracted using $\mathrm{KCl}$ solution (Mirschel et al., 2007). The measured soil data are:

- soil water in 0-30 cm depth ( $\mathrm{Vol} \%)$

- soil water in 30-60 cm depth ( $\mathrm{Vol} \%)$

- soil water in $60-90 \mathrm{~cm}$ depth ( $\mathrm{Vol} \%)$

- soil nitrate in 0-30 $\mathrm{cm}$ depth $\left(\mathrm{kg} \mathrm{ha}^{-1}\right)$

- soil nitrate in 30-60 $\mathrm{cm}$ depth $\left(\mathrm{kg} \mathrm{ha}^{-1}\right)$

- soil nitrate in $60-90 \mathrm{~cm}$ depth $\left(\mathrm{kg} \mathrm{ha}^{-1}\right)$

- soil ammonium in 0-30 $\mathrm{cm}$ depth $\left(\mathrm{kg} \mathrm{ha}^{-1}\right)$

- soil ammonium in 30-60 $\mathrm{cm}$ depth $\left(\mathrm{kg} \mathrm{ha}^{-1}\right)$

- soil ammonium in 60-90 $\mathrm{cm}$ depth $\left(\mathrm{kg} \mathrm{ha}^{-1}\right)$.

The soil temperatures were measured every 10 minutes using "PT100" epoxy-embedded thermistors with an accuracy of $0.2 \mathrm{~K}$. They were then aggregated to mean daily soil temperatures (see section3.1). For depths at $5 \mathrm{~cm}, 20 \mathrm{~cm}$ and $50 \mathrm{~cm}$, the thermistors were located about $2.5 \mathrm{~m}$ from the micro-meteorological station under grass, not in the plots covered by agricultural crops (crop rotation see section 2.2).

3.2.2 PROFILE DESCRIPTION: The significant physical and chemical properties for the soil profile down to a depth of $200 \mathrm{~cm}$ for all three plots are given in Table 1. To determine soil properties for the deeper horizons was not possible. Additional information on soil characteristics and soil profiles for ZALF Experimental Station is provided in Schindler (1980).

Table 1. Soil properties measured at all three plots covered with different cropping systems (taken from Mirschel et al., 2007, modified)

\begin{tabular}{llccccccccc}
\hline Plot & Horizon & Depth & Sand & Silt & Clay & $\begin{array}{c}\text { Organic } \\
\text { carbon } \\
(\mathbf{6})\end{array}$ & $\begin{array}{c}\text { Total } \\
\text { nitrogen } \\
\mathbf{( \% )}\end{array}$ & C:N & pH & $\begin{array}{c}\text { Bulk } \\
\text { density } \\
\left.\mathbf{( g ~ c m}^{-3}\right)\end{array}$ \\
\hline 1 & Ap & $0-30$ & 83 & 9 & 8 & 0.66 & 0.054 & 12.1 & 6.1 & 1.45 \\
& Ael & $30-60$ & 86 & 8 & 6 & 0.16 & 0.015 & 11 & 6.1 & 1.5 \\
& Bt & $60-90$ & 72 & 14 & 14 & 0.08 & 0.007 & 11.1 & 6.3 & 1.55 \\
C1 & $90-110$ & 83 & 10 & 7 & n.a & n.a & n.a & n.a & n.a \\
& C2 & $110-160$ & 92 & 7 & 1 & n.a & n.a & n.a & n.a & n.a \\
\hline
\end{tabular}




\begin{tabular}{|c|c|c|c|c|c|c|c|c|c|c|}
\hline Plot & Horizon & $\begin{array}{l}\text { Depth } \\
\text { (cm) }\end{array}$ & $\begin{array}{l}\text { Sand } \\
\text { (\%) }\end{array}$ & $\begin{array}{l}\text { Silt } \\
\text { (\%) }\end{array}$ & $\begin{array}{l}\text { Clay } \\
\text { (\%) }\end{array}$ & $\begin{array}{c}\text { Organic } \\
\text { carbon } \\
(\%)\end{array}$ & $\begin{array}{c}\text { Total } \\
\text { nitrogen } \\
(\%)\end{array}$ & C:N & $\mathrm{pH}$ & $\begin{array}{c}\text { Bulk } \\
\text { density } \\
\left(\mathrm{g} \mathrm{cm}^{-3}\right)\end{array}$ \\
\hline 1 & C3 & $160-210$ & 98 & 1 & 1 & n.a & n.a & n.a & n.a & n.a \\
\hline \multirow[t]{6}{*}{2} & Ap & $0-30$ & 83 & 9 & 8 & 0.58 & 0.05 & 11.6 & 6.5 & 1.45 \\
\hline & Ael & $30-90$ & 93 & 6 & 1 & 0.13 & 0.013 & 10 & 6.5 & 1.5 \\
\hline & Bt1 & $90-130$ & 78 & 12 & 10 & n.a & n.a & n.a & n.a & 1.55 \\
\hline & $\mathrm{Bt} 2$ & $130-170$ & 80 & 11 & 9 & n.a & n.a & n.a & n.a & n.a \\
\hline & $\mathrm{C} 1$ & $170-180$ & 97 & 2 & 1 & n.a & n.a & n.a & n.a & n.a \\
\hline & $\mathrm{C} 2$ & $180-225$ & 98 & 1 & 1 & n.a & n.a & n.a & n.a & n.a \\
\hline \multirow[t]{4}{*}{3} & Ap & $0-30$ & 83 & 9 & 8 & 0.62 & 0.054 & 11.4 & 6.3 & 1.45 \\
\hline & Ael & $30-100$ & 93 & 6 & 1 & 0.13 & 0.013 & 10 & 6.3 & 1.5 \\
\hline & Bt1 & $100-110$ & 65 & 18 & 17 & n.a & n.a & n.a & n.a & 1.55 \\
\hline & Bt2 & $110-225$ & 84 & 7 & 9 & n.a & n.a & n.a & n.a & n.a \\
\hline
\end{tabular}

n.a. - not available

\subsection{CROP DATA}

3.3.1 ONTOGENESIS AND BIOMASS: The BBCH scale (Hack et al., 1992) for cereals and sugar beet, a decimal code system used in Germany, identical to the decimal code system according to Zadoks (1974), was used for describing the plant development. The development stages of all crops at the three plots between emergence and maturity were estimated weekly.

For winter wheat, winter barley and winter rye the numbers for plants, tillers and ears were determined within a $1 \mathrm{~m}^{2}$ section in nine randomised replicates. For sugar beet, the plant number was determined based on a 9.6-m long row section (approximately $4 \mathrm{~m}^{2}$ ) in nine randomised replicates. For all plots finally an average was calculated.

In the manually harvested sub-plots, above-ground and root biomasses were determined periodically. At each of the three plots, three randomised replicates for cereals and sugar beet were taken as mixed samples. At each sampling date samples were taken from $0.25 \mathrm{~m}^{2}$ sections for cereals and $1 \mathrm{~m}^{2}$ sections, i.e. a $2.4 \mathrm{~m}$ long row section, for sugar beet. The material of all three replicate subsamples harvested was separated into stem/leaves and ears (including grain, glume and rest of the ear) for cereals and into beet and leaves (including petioles) for sugar beet. For all biomass fractions the fresh biomass was measured. The root biomass from a top $30 \mathrm{~cm}$ soil layer was determined for cereals only. For dry biomass determination $1000 \mathrm{~g}$ fresh biomass probes (subsamples) were taken from each biomass fraction and oven-dried at around $60^{\circ} \mathrm{C}$ for two to three days. The sugar content for sugar beet was measured using an automatic light-electric polarimeter "POLAMAT S" (Strube and Scholze, 1970). The measured values for ontogenesis, dry biomass and the crop stand are:

- ontogenesis stage (DC-Code)

- number of plants $\left(\mathrm{m}^{-2}\right)$

- number of tillers $\left(\mathrm{m}^{-2}\right)$

- number of ears $\left(\mathrm{m}^{-2}\right)$

- shoot dry biomass (stem \& leaf; $\mathrm{kg} \mathrm{ha}^{-1}$ )

- root dry biomass $\left(\mathrm{kg} \mathrm{ha}^{-1}\right)$

- storage organ (ear/beet) dry biomass ( $\left.\mathrm{kg} \mathrm{ha}^{-1}\right)$

- sugar content (\%).

3.3.2 CARBON AND NITROGEN IN BIOMASS: For determination of total crop nitrogen and total crop carbon the dried biomass probes were milled. For extraction the total crop nitrogen the Kjeldahl method (Bock, 1972) was used. The nitrogen compounds were analysed using the spectrophotometric analysis at $578 \mathrm{~nm}$ (photometer EPOS 5060 produced by Eppendorf). For determining the total crop carbon an elementary analysis was used. The biomass probes were incinerated within an oxygen environment at $1250^{\circ} \mathrm{C}$. After oxidation, the quantity of $\mathrm{CO}_{2}$ gas was measured using the element analyser CNS 2000 (Leco, St. Joseph, MI, USA). 
The measured values for crop nitrogen and crop carbon are:

- carbon in above-ground biomass - stem \& leaves - $\left(\mathrm{kg} \mathrm{C}^{-1}\right)$

- carbon in root biomass $\left(\mathrm{kg} \mathrm{C} \mathrm{ha}^{-1}\right)$

- carbon in storage organ (ear/beet) biomass $\left(\mathrm{kg} \mathrm{C} \mathrm{ha}^{-1}\right)$

- nitrogen in above-ground biomass -stem \& leaves- $\left(\mathrm{kg} \mathrm{N} \mathrm{ha}^{-1}\right)$

- nitrogen in root biomass $\left(\mathrm{kg} \mathrm{N} \mathrm{ha}^{-1}\right)$

- nitrogen in storage organ (ear/beet) biomass $\left(\mathrm{kg} \mathrm{N} \mathrm{ha}^{-1}\right)$.

4. DATA BASE STRUCTURE AND AVAILABILITY: The open research data set described above is structured into six tables. All table names begin with V004, the experiment internal code. Table 2 shows the data set tables and their structure.

The six-year data set described above for all modellers and other scientists is freely available via doi: 10.4228/ZALF.1992.167. The data tables in the downloaded zip-files have a xml- as well as a csvformat (comma-separated values). Additionally, via doi: 10.4228/ZALF.1992.167 a brief description of the methods used for data acquisition is shown as well as information about the location of the three field plots at ZALF Experimental Station are given. The weather data from the meteorological station Müncheberg for the time period 1992-1998 described above also are freely available for the individual years as follows:

- via doi: 10.4228/ZALF.1992.108 for 1992

- via doi: 10.4228/ZALF.1993.112 for 1993

- via doi: 10.4228/ZALF.1996.115 for 1996

- via doi: 10.4228/ZALF.1994.113 for 1994

- via doi: 10.4228/ZALF.1997.116 for 1997

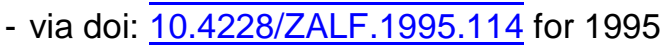

- via doi: 10.4228/ZALF.1998.117 for 1998.

Table 2. Overview of all data set tables

\begin{tabular}{|c|c|}
\hline Table name: V004 & Content and comments \\
\hline _MANAGEMENT & $\begin{array}{l}\text { The management information is listed after the plot } \\
\text { number, starting with the crop type and the cultivar; all } \\
\text { other columns see section } 2.3 \text {. }\end{array}$ \\
\hline $\begin{array}{l}\text { MUENCHEBERG } \\
\text { WEATHER_92_98 }\end{array}$ & $\begin{array}{l}\text { The first table columns are: date (dd.mm.yyyy), year, } \\
\text { month, day, Julian day; all other columns see section } \\
\text { 3.1. }\end{array}$ \\
\hline _SOIL_H2O_NMIN_CONTENT & $\begin{array}{l}\text { The table columns are: plot number, date } \\
\text { (dd.mm.yyyy), year, month, Julian day; all other } \\
\text { columns see section 3.2.1. }\end{array}$ \\
\hline _SOIL_PLOT & $\begin{array}{l}\text { After the plot number, all necessary soil properties for } \\
\text { the three plots are listed (order see Table 1). }\end{array}$ \\
\hline _CROP_ONTOGENESIS_BIOMASS & $\begin{array}{l}\text { The first table columns are: plot number, date } \\
\text { (dd.mm.yyyy), year, month, day, Julian day and crop } \\
\text { type; all other columns see section 3.3.1. }\end{array}$ \\
\hline _CROP_CARBON_NITROGEN & $\begin{array}{l}\text { The first table columns are: plot number, date } \\
\text { (dd.mm.yyyy), year, month, day, Julian day and crop } \\
\text { type; all other columns see section 3.3.2. }\end{array}$ \\
\hline
\end{tabular}

5. AUTHOR CONTRIBUTION: W. Mirschel, K.-O. Wenkel and K.C. Kersebaum designed the whole experiment. D. Barkusky and G. Rosner carried out the experiment, were responsible for crop and soil data measurement and documented all management information. K. Luzi and L. Laacke created the data base and prepared it for the Open Research Data Portal of the ZALF Müncheberg. W. Mirschel prepared the manuscript with contributions from all co-authors.

6. ACKNOWLEDGEMENTS: The authors are grateful to M. Bähr, E. Klank, S. Dittmar, P. Eisermann, G. Bähr and F. Reining, as representatives of all those involved in the sampling and measuring processes. We would also like to thank our colleagues at ZALF Experimental Station for conducting the field experiments. Last but not least, the authors would like to acknowledge the support received from the German Federal Ministry of Food and Agriculture, the German Federal Ministry of Education and Research and the Brandenburg Ministry of Sciences, Research and Cultural Affairs. 


\section{REFERENCES}

Bock, R. 1972. "Aufschlussmethoden der anorganischen und organischen Chemie." Verlag Chemie, Weinheimpp. $232 \mathrm{pp}$.

Brisson, N., Gary, C., Justes, E., Roche, R., Mary, B., Ripoche, D., Zimmer, D., Sierra, J., Bertuzzi, P., Burger, P., Bussiere, F., Cabidoche, Y.M., Cellier, P., Debaeke, P., Gaudillere, J.P., Henault, C., Maraux, F., Seguin, B., Sinoquet, H. 2003. "An overview of the crop model STICS." European Journal of Agronomy 18(3): 309-332. doi: 10.1016/S1161-0301(02)00110-7.

Diekkrüger, B., Söndgerath, D., Kersebaum, K.C., McVoy, C.W. 1995. "Validity of agroecosystem models - A comparison of results of different models applied to the same data set." Ecological Modelling 81 (NOS.1-3; Special Issue: Validation of Agroecosystem Models): 3-29. doi: 10.1016/0304-3800(94)00157-D.

Efroymson, R.A., Kline, K.L., Angelsen, A., Verburg, P.H., Dale, V.H., Langeveld, J.W.A., McBride A. 2016. "A causal analysis framework for land-use change and the potential role of bioenergy policy." Land Use Policy 59:16-27. doi: 10.1016/.landusepol.2016.09.009.

Hack H., Bleiholder H., Buhr L., Meier U. Schnock-Fricke U., Weber E.,Witzenberger A. 1992. "Einheitliche Codierung der phänologischen Entwicklungsstadien mono- und dikotyler Pflanzen Erweiterte BBCH-Skala." Allgemein.- Nachrichtenbl. Deut Pflanzenschtzd. 44: 265-270.

Hansen, S., Abrahamsen, P., Petersen, C.T., Styczen, M. 2012. „Daisy: Model use, calibration and validation". Trans. ASABE 55: 1315-1333. doi: 10.13031/2013.42244.

Keating, B.A., Carberry, P.S., Hammer, G.L., Probert, M.E., Robertson, M.J., Holzworth, D., Huth, N.I., Hargreaves, J.N.G., Meinke, H., Hochman, Z. 2003. "An overview of APSIM, a model designed for farming systems simulation." European Journal of Agronomy 18: 267-288. doi: 10.1016/S1161-0301(02)00108-9.

Kersebaum, K.C. 2011. "Special features of the HERMES model and additional procedures for parameterization, calibration, validation, and applications." Methods of Introducing System Models into Agricultural Research: 65-94. doi: http://doi.org/10.2134/advagricsystmodel2.c2.

Kersebaum, K.-C., Boote, K. J., Jorgenson, J. S., Nendel, C., Bindi, M., Frühauf, C., Gaiser, T., Hoogenboom, G., Kollas, C., Olesen, J. E., Rötter, R. P., Ruget, F., Thorburn, P. J., Trnka, M., Wegehenkel, M. (2015). „Analysis and classification of data sets for calibration and validation of agro-ecosystem models." Environmental Modelling \& Software 72, 402-417. doi: 10.1016/j.envsoft.2015.05.009.

Kersebaum,K.C., Hecker, J.-M., Mirschel, W., Wegehenkel, M. (eds.) 2007. "Modelling Water and Nutrient Dynamics in Soil-Crop Systems: proceedings of the workshop on "Modelling water and nutrient dynamics in soil-crop systems" held on 14-16 June 2004 in Müncheberg, Germany." 271 p., Dordrecht (Springer). doi: 10.1007/978-1-4020-4479-3.

Kersebaum, K.C., Nendel, C. 2014. „Site-specific impacts of climate change on wheat production across regions of Germany using different $\mathrm{CO} 2$ response functions." European Journal of Agronomy 52: 22-32. doi: 10.1016/i.eja.2013.04.005.

Kollas, C., Kersebaum, K.-C., Nendel, C., Manevski, K., Müller, C., Palosuo, T., Armas-Herrera, C. M., Beaudoin, N., Bindi, M., Charfeddine, M., Conradt, T., Constantin, J., Eitzinger, J., Ewert, F., Ferrise, R., Gaiser, T., de Cortazar-Atauri, I. G., Giglio, L., Hlavinka, P., Hoffmann, H., Hoffmann, M. P., Launay, M., Manderscheid, R., Mary, B., Mirschel, W., Moriondo, M., Olesen, J. E., Öztürk, I., Pacholski, A., Ripoche-Wachter, D., Roggero, P. P., Roncossek, S., Rötter, R. P., Ruget, F., Sharif, B., Trnka, M., Ventrella, D., Waha, K., Wegehenkel, M., Weigel, H.-J., Wu, L. 2015. "Crop rotation modelling - a European model intercomparison." European Journal of Agronomy 70: 98111. doi: 10.1016/i.eja.2015.06.007.

Martre, P., Wallach, D., Asseng, S., Ewert, F., Jones, J. W., Rötter, R. P., Boote, K. J., Ruane, A. C., Thorburn, P. J., Cammarano, D., Hatfield, J. L., Rosenzweig, C., Aggarwal, P. k., Angulo, C., Basso, B., Bertuzzi, P., Biernath, C., Brisson, N., Challinor, A. J., Doltra, J., Gayler, S., Goldberg, R., Grant, R. F., Heng, L., Hooker, J., Hunt, L. A., Ingwersen, J., Izaurralde, R. C., Kersebaum, K.-C., Müller, C., Kumar, S. N., Nendel, C., O'Leary, G., Olesen, J. E., Osborne, T. M., Palosuo, T., Priesack, E., Ripoche, D., Semenov, M. A., Shcherbak, I., Steduto, P., Stöckle, C. O., Stratonovitch, P., Streck, T., Supit, I., Tao, F., Travasso, M., Waha, K., White, J. W., Wolf, J. 2015. "Multimodel ensembles of wheat growth: many models are better than one." Global Change Biology 21(2): 911-925. doi: 10.1111/gcb.12768.

Mirschel, W., Schultz, A., Wenkel, K.-O. 2001. "Assessing the Impact of Land Use Intensity and Climate Change on Ontogenesis, Biomass Production, and Yield of Northeast German Agrolandscapes." In: Tenhunen, J.D., Lenz, R., Hantschel (eds.): Ecosystem Approaches to Landscape Management in Central Europe. Ecological Studies, Vol. 147, Springer-Verlag Berlin Heidelberg, New York, 2001, p. 299-313. 
Mirschel, W., Wenkel, K.-O. 2007. "Modelling soil-crop interactions with AGROSIM model family." In: Kersebaum, K.C.; Hecker, J.-M.; Mirschel, W.; Wegehenkel, M. (eds.): Modelling Water and Nutrient Dynamics in Soil-Crop Systems: proceedings of the workshop on "Modelling water and nutrient dynamics in soil-crop systems" held on 14-16 June 2004 in Müncheberg, Germany, Dordrecht (Springer), 59:73. doi: 10.1007/978-1-4020-4479-3.

Mirschel, W., Wenkel, K.-O., Wegehenkel, M., Kersebaum, K.C., Schindler, U. 2015. Comprehensive multivariable field data set for agro-ecosystem modelling from Muencheberg Experimental Station in 1992 - 1998. Leibniz-Zentrum für Agrarlandschaftsforschung (ZALF) e.V. doi: 10.4228/ZALF.1992.167.

Mirschel, W., Wenkel, K.-O., Wegehenkel, M., Kersebaum, K.C., Schindler, U., Hecker, J.M. 2007. "Müncheberg field trial data set for agro-ecosystem model validation." In: Kersebaum, K.C., Hecker, J.M., Mirschel, W., Wegehenkel, M. (eds.): Modelling Water and Nutrient Dynamics in Soil-Crop Systems: proceedings of the workshop on "Modelling water and nutrient dynamics in soil-crop systems" held on 14-16 June 2004 in Müncheberg, Germany, pp. 59-73, Dordrecht (Springer). doi: 10.1007/978-1-4020-4479-3.

Nendel, C., Berg, M., Kersebaum, K.-C., Mirschel, W., Specka, X., Wegehenkel, M., Wenkel, K.-O., Wieland, R. 2011. "The MONICA model: Testing predictability for crop growth, soil moisture and nitrogen dynamics." Ecological Modelling 222(9): 1614-1625. doi: 10.1016/j.ecolmodel.2011.02.018.

Schindler, U. 1980. "Ein Schnellverfahren zur Messung der Wasserleitfähigkeit im teilgesättigten Boden an Stechzylinderproben." Arch. Acker-, Pflanzenbau und Bodenkunde 24: 1-7.

Stöckle, C.O., Donatelli, M., Nelson, R. 2003. "CropSyst, a cropping systems simulation model." European Journal of Agronomy 18: 289-307. doi: 10.1016/0308-521X(94)90006-2.

Strube W., Scholze D. 1970. "Erprobung des automatischen Polarimeters POLAMAT S." LebensmittelIndustrie 1970(11): 2-4.

Wehrmann J. and Scharpf H.-C. 1979. "Der Mineralstickstoffgehalt des Bodens als Maßstab für den Stickstoffdüngungsbedarf (Nmin-Methode)." Plant and Soil 52: 109-126. doi: 10.1007/BF02197737.

Wenkel, K.-O., Mirschel, W. (eds.) 1995. "Agroökosystemmodellierung - Grundlage für die Abschätzung von Auswirkungen möglicher Landnutzungs- und Klimaänderungen." ZALF-Bericht, 24: $187 \mathrm{pp}$.

Zadoks J.C., Chang, T.T., Konzak, C.F. 1974. "A decimal code for growth stages of cereals." Weed Res. 14: 415-421. 